\title{
The Attitude of Communicating Using Language in Maintaining Cultural Cohesion in the Gilimanuk- Jembrana-Bali Multicultural Society
}

\author{
IBP Manuaba ${ }^{1}$, NW Sartini ${ }^{2}$, \\ \{1ibputeramanuaba@gmail.com, 2yaniwiratha@yahoo.com $\}$ \\ ${ }^{1,2}$ Universitas Airlangga
}

\begin{abstract}
The attitude of communicating languages in multicultural societies that have ethnic diversity, often becomes an obstacle, which results in not building cultural cohesion. Therefore, there needs to be a model of attitude to communicate using different languages, as is done in the Gilimanuk-JembranaBalinese multicultural society, which tends to not only use the language of one's own tribe but also the language of other tribes. The research method used in this study is a qualitative-field research method, data are collected using in-depth interview techniques and observation techniques, data in the form of language attitudes of multicultural communities, and locations are multicultural communities of Gilimanuk-Jembrana-Bali. The original finding in this research is a flexible communication attitude using language. The attitude of communication that uses other ethnic languages in languages is very functional in maintaining cultural cohesion (social harmony) in multicultural societies. To be flexible in communicating using language in a multicultural society, each member of the community must have multilingual abilities and are not fanatical about their ethnic language. The results of this study indicate that the flexible attitude of communication using language in multicultural societies, in fact, not only serves to convey information (messages), but also there is a noble intention to build intimacy in the community to maintain cultural cohesion (cultural harmony)
\end{abstract}

Keywords: communication attitude, multicultural society, flexible attitude, cultural cohesion (social harmony).

\section{Introduction}

Indonesia as a nation, has been known in the world as a diverse (multicultural) nation, and Tilaar [1] calls it a diverse nation. The diversity of Indonesian culture is not only in terms of ethnicity, but also in religion, race and sect. In terms of ethnicity, Indonesia has 17,000 tribes, as well as six religions and beliefs, as well as various races and sects.

In multicultural societies in Indonesia, diversity is often responded to negatively and even as if seen as obstacles. As a result, often from such perceptions, it grows into social conflicts 
(horizontal), even though the conflict is situational - sometimes it arises and sinks. However, with diversity, it seems that the fire of conflict is always there.

This social conflict should not need to happen, if the reason is only because it is different. The attitude of not being able to accept this difference, occurring in many societies or social groups in Indonesia, raises claims: majority versus minority, dominant versus marginal, mainstream and non-mainstream. Sectoral ego - feeling the best of others and feeling the most right - often triggers conflict. Because in diversity, there are tribes and religions who feel themselves more than others. Conditions like this, occur almost evenly in the territory of Indonesia.

For this reason, such conditions require appropriate solutions and ideas to overcome them, so that the community can maintain social harmony in the life of the nation and state. If this difference is understood as a necessity, then the difference should be responded positively. That is, there is no reason if the difference is used as an obstacle in building cultural cohesion (social harmony). Ideally, there needs to be a solution in caring for social harmony, which can be done in an attitude of communication using language. Therefore, this study specifically aims to illustrate the importance of communication using language to maintain cultural cohesion.

In this research paper, it is known that there are several regions in Indonesia that have local wisdom that can be explored and used as a solution in managing multicultural societies. Something ideal is important, so that differences are not understood as obstacles (obstacles), but in order to be understood as potential in building cultural cohesion (social harmony).

One of the fields referred to here is local wisdom in the Gilimanuk-Jembrana-Bali multicultural society. Why choose Gilimanuk? Therefore, the Gilimanuk community is one of the most diverse multicultural societies in Indonesia. In the diversity of the Gilimanuk community, this society manages diversity sympathetically, so that the Gilimanuk community can be a society that has cultural cohesion (social harmony).

The Gilimanuk community is part of a multilingual Indonesian society [2]. One uniqueness that is known to exist in the Gilimanuk multicultural society is one's flexible attitude in using tribal language. That is, there is mastery in all ethnic languages in Gilimanuk which is multicultural. So, someone uses tribal multilingualism, and not just bilingual - like the Pastika [3] concept which he calls balanced bilingualism (one language is derived from family and one language is obtained from school).

Therefore, using what ethnic language should be when communicating in the Gilimanuk community, depends very much on who a person is and what ethnic group someone is communicating with. This language attitude is consistent with what was said in Anderson NH's thinking [4] that social integration does require changes in a person's attitude in communicating using language.

Based on the literature study that has been done, it is known that no one specifically addresses the focus of this research. This focus also intends to offer something original to solve language problems in multicultural societies. It is known, there have been several papers that have been written relating to multicultural languages, there are writers who write papers on multiculturalism in Indonesia [5]. Then, there are also writings on regional languages (Sundanese) as tribal languages in the middle of the global era [6]. Then, there are also papers that discuss local languages as a representation of science [7]. Wibowo and Retnaningsih [8], specifically examined the greeting attitude as the attitude of one's language. Wagiati and colleagues [9] examined language attitudes among adolescents in Sundanese in Bandung, the results of which showed a positive attitude. Jenkins [10] conducted research on language 
attitudes, but more in learning English with a teacher who has an identity. However, all of these writings, have not reviewed the focus in this paper.

So, in this study, the focus of the research is on efforts to identify the diversity of the Gilimanuk multicultural society and the attitudes of people in the Gilimanuk community in using tribal language in social interaction, so that cultural cohesion (social harmony) is maintained. To test this focus, field research data was used in the Gilimanuk-Jembrana-Bali community.

\section{Research Method}

The article of this study uses a qualitative-field research design. Moleong [11] said that this qualitative research was oriented to thinking orientation. Gilimanuk-Jembrana-Bali, The object of this study is the attitude of speaking with language in the community. Research data were collected by techniques: first, in-depth interviews with informants in the GilimanukJembrana-Bali community; second, field observations on the language practices of the Gilimanuk-Jembrana-Bali multicultural community. The validity of the data, collected in accordance with the focus of the study. Data that has been collected, then collected, collected, and reviewed with sociological language analysis techniques. In this analysis, it can be seen the extent of people's attitudes towards social in social harmony or social cohesion in the lives of multicultural communities in Gilimanuk-Jembrana-Bali.

\section{Results And Discussion}

The Gilimanuk society is a society that determines the attitude of language as a very important part. This society is very concerned with the politeness of language in the society. For this reason, in the Gilimanuk society, language is positioned as an important part in building the comfort of people in Gilimanuk who support and satisfy each other. In Gilimanuk society, language is a major part of social interaction, which is very important for intimacy and togetherness, especially in relation to cultural cohesion (social harmony).

As noted, ethnic diversity affects ethnic language diversity. Thus, the diversity of tribes in Gilimanuk (Java, Bali, Madura, Lombok and Bugis) also automatically makes language diverse in Gilimanuk. In the Gilimanuk society, a variety of languages is managed wisely - the same as managing other types. Interestingly, various languages are used conditionally and situationally.

That is, supporting a variety of languages, the Gilimanuk people highly value and respect all languages that live in the Gilimanuk society. Everyone who lives in society positions language in equality. There is no opinion of the public, there is a language that is better or superior. All languages in the Gilimanuk society are well managed and managed, without favoritism.

In principle, the Gilimanuk society, as a multicultural society, are well aware of diversity as a potential that must be managed properly and wisely. If outside the Gilimanuk society, the language used to communicate in cultural diversity is only Indonesian. Unlike the people in Gilimanuk society, besides using Indonesian, tribal language is also used to communicate in cultural diversity. 
Therefore, in the reality of language in the Gilimanuk society, someone in the Gilimanuk society uses multilingual language. For example, when someone communicates with Balinese, even if someone is not from a Balinese background, then someone tends to use Balinese. When someone communicates with a Javanese person, even though someone is not from a Javanese background, someone in the Gilimanuk society interaction tends to use Javanese.

Likewise in the Gilimanuk society dialect, which also tends to use it flexibly, and changes from the tribal language used. Therefore, it really depends on who a person is communicating. This is very interesting, because in language interaction in the Gilimanuk society, there is a flexible attitude in using language. This flexibility, in pragmatic language practices, is possible if someone in the community is not fanatical about their ethnic language [12][13]. This is because through the language used, people feel experiencing emotional closeness.

To be able to use tribal and dialect languages with a flexible attitude, everyone in the Gilimanuk socieity must master the tribal languages that exist and still live in the Gilimanuk society [14]. Without the attention and understanding of other tribal languages, communication flexibility in using language is not possible. Therefore, in the Gilimanuk community, a person in the Gilimanuk society must master more than one ethnic language.

The lives of the Gilimanuk people, who are sociologically and domicile, live in mingle and together with each other, enable their people to master more than one ethnic language [15]. Besides the tribal language itself, the average person in the Gilimanuk society also masters other tribal languages. Conditions and attitudes of communication in using this language do not occur in other regions in Indonesia. All this seems only to occur in the Gilimanuk society, because in this society language has a very important role to maintain tolerance in diversity in the Gilimanuk society.

\section{Conclusion}

In this paper, there are four important conclusions that can be discussed here. The four conclusions related to language attitudes in the Gilimanuk multicultural society are as follows.

First, in the multicultural society Gilimanuk which is very diverse in terms of ethnicity, will also automatically have diverse languages. Tribal language becomes tribal identity. The tribes in the Gilimanuk society, which have been integrated in a multicultural society, have mixed. The Gilimanuk society, which has various groups that live together in languages, does not become a barrier to supported development. Conversely, ethnic and language diversity is well managed and wisdom in languages that are flexible, speak using the language and dialect of other tribes.

Second, discussing the various tribes in the Gilimanuk society, is positioned equally, although in terms of population numbers are not the same. All tribal languages in the Gilimanuk society, considered to belong to the Gilimanuk society, are a wealth of languages that are preserved, controlled, and used to save cultural cohesion (social harmony) in the Gilimanuk society.

Third, with diverse language positions in the Gilimanuk society, it can provide various tribes in the comfortable Gilimanuk society as one Gilimanuk extended family. All existing tribal languages belong to the Gilimanuk society, and can be used conditionally and situationally. This pattern is useful for managing any multicultural society.

Fourth, with the conditioning of language in Gilimanuk society like that, language no longer only has a communication function, but also has the function of preserving and 
preserving culture. The multicultural needs of the Gilimanuk society which are full of attitude and spirit of tolerance, are well maintained and can be sustainable, because of the value of local wisdom that lives in the Gilimanuk community. The management of language in this society can benefit the Gilimanuk society, and can also set the pattern for managing multicultural societies in Indonesian territory and also any multicultural society.

\section{Acknowledgement}

The author thanks the Director of Research and Community Service, Ministry of Research and Technology of the Republic of Indonesia for funding this research. Thank you also to the Research and Innovation Institute of Airlangga University, for processing all research administrative needs. In addition, thanks to the Dean of the Faculty of Humaninities, Airlangga University, and also the Indonesian Language and Literature Department, Faculty of Humanities, Airlangga University. Also the informants in the field, and also the research team who have helped in collecting research data, as well as those who cannot be mentioned one by one here.

\section{References}

[1] I. Zulaeha, "Development of Skill Learning Models in Multicultural Contexts in Indonesian Language," Litera J. Penelit. Bahasa, Sastra, dan Pengajaranya, vol. 12, no. 1, pp. 97-105, 2013.

[2] A. Chaer, Sosiolinguistik Perkenalan Awal. Jakarta: Rineka Cipta, 2014.

[3] I. W. Pastika, The Approach to Maturity Since Early Childhood: Indonesian and Regional Languages. Yogyakarta: Pustaka Pelajar, 2014.

[4] N. Anderson, "Integration Theory and Attidute Change," Psychol. Rev., vol. 78, no. 3, pp. 171206, 1971.

[5] H. Jie, "Study on Multiculturalism of Bahasa Indonesia from Assimililation of Loanwords," in Proceedings of International Seminars of The Relationship of Locality towards the Modernity of Indonesian Language and Literature, 2009, pp. 4-7.

[6] C. Sobarna, "Regional Language Life (Sundanese) in the Global Era: Setback or Moderate?," in Proceedings of the International Seminar of The Relationship of Locality to the Modernity of Indonesian Language and Literature, 2009, pp. 21-24.

[7] F. Rahyono, "Local Language as a Representative of Science," in Proceedings of the National Seminar on Mother Language VIII, 2015, p. 73.

[8] Wibowo, "The Dynamics of Greeting Forms as Reflections on the Indonesian Language's Attitude," Humaniora, vol. 27, no. 3, 2015.

[9] N. Wagiati, "Language Attitudes of Sundanese Language Youths in Bandung Regency: A Sociolinguistic Study," Metalingual, vol. 15, no. 2, 2017.

[10] J. Jenkins, English as a Lingua Franca: Attitude and Identity. Oxford, GB: Oxford University Press, 2007.

[11] L. J. Moleong, Metodologi Penelitian Kualitatif. Bandung: PT. Remaja Rosdakarya, 1990.

[12] Sumarni, "The Results of Interviews with Informants on August 6, 2019," Gilimanuk Jembrana Bali, 2019.

[13] K. Saddhono, "Language of coastal communities in the northern coast of central java: sociolinguistic studies in cultural integration maritime-agrarian perspective," Adv. Sci. Lett., vol. 23, no. 10, pp. 10054-10056, 2017.

[14] Made, "The Results of Interviews with Informants on August 6, 2019," Gilimanuk Jembrana- 
Bali, 2019.

[15] G. Ngurah, "Interview Results Interview with Informants on August 5, 2019," Gilimanuk Jembrana-Bali, 2019. 